University of Nebraska - Lincoln

DigitalCommons@University of Nebraska - Lincoln

To Improve the Academy

Professional and Organizational Development Network in Higher Education

1995

Academic Syndromes Revisited

Robert R. Dove

Follow this and additional works at: https://digitalcommons.unl.edu/podimproveacad

Part of the Higher Education Administration Commons

Dove, Robert R., "Academic Syndromes Revisited" (1995). To Improve the Academy. 331.

https://digitalcommons.unl.edu/podimproveacad/331

This Article is brought to you for free and open access by the Professional and Organizational Development Network in Higher Education at DigitalCommons@University of Nebraska - Lincoln. It has been accepted for inclusion in To Improve the Academy by an authorized administrator of DigitalCommons@University of Nebraska - Lincoln. 


\section{Academic Syndromes Revisited}

\section{Robert R. Dove}

Pittsburgh Technical Institute

This article describes a workshop designed for students and faculty that is based on Herman Blake's research on Academic Syndromes of Minority Students. Blake presented the results of his research at the 1980 POD Conference and what he had to say then has even broader applications now. The workshop explores the roles of Ultimate Doom, Getting Over and Alienation in the lives of our students. The author suggests that this workshop could be an integral part of an effective retention effort for many schools.

In October of 1980, I attended my first POD Conference and came away, as always, with information that was very useful. One particular presentation provided food for thought and a basis for continuous application and research. Herman Blake, then Provost of Oakes College, University of California at Santa Cruz, introduced a group of us to the results of 18 months of research on student "academic syndromes." I have presented the results of his research to the faculty at three different institutions during the past 14 years. I also developed a workshop for freshmen based on his comments and have presented it in more than 100 classes. My own research shows that what he had to say then has even broader applications now. 


\section{Background}

Blake's research, done in the late 1970's, was based on interviews with ethnic minority college students through 18 months of their college experience at Oakes College. It grew out of Blake's desire to help the faculty deal with a 40-50\% non-traditional student body. He stated, "there is nothing wrong with having confidence in your own background until it gets in the way. Being black still did not make us understand the experience of our students."(Blake, 1980) The analysis of 100 interviews with ethnic minority students revealed three major patterns of behavior, or syndromes, that greatly affected their ability to succeed in school. The three syndromes identified were Ultimate Doom, the Getting Over Pattern, and Alienation.

The students with Ultimate Doom felt that they would inevitability fail at something before they even began. They expected failure. They only wondered when it would come. Blake's research revealed that students with feelings of Ultimate Doom tended to make it a self-fulfilling prophecy. Whether it was Math or English or any course they had failed before, they convinced themselves that they weren't any good at that subject and proceeded to fail the class again. Ultimate Doom for some of these students meant that they were more anxious the closer they got to commencement. They couldn't accept success. Even if they did well through three years of college, they managed to fail during their final year.

The second syndrome identified was the Getting Over Pattern. Students who were into Getting Over tried to "beat the system." As a psychological defense against failure, they would do as little work as possible and try to impress the teacher with their intentions rather than their actions. If they didn't pass the course, they wouldn't feel like failures because they didn't invest very much of themselves in an effort to pass. Contrary to his original perceptions, Blake found that having ethnic minority faculty members did not eliminate students trying to "get over" on them. Each student was dealing with a fear of failure and this had nothing to do with racial identity.

Just as the student with feelings of Ultimate Doom seemed to focus on an "F" grade as an expectation, the "Getting Over" student seemed to focus on a "C" grade. Their goal was to do as little work as 
possible to earn a "C." A strategy that worked so well in high school where the goal was to graduate, not necessarily to learn.

The third syndrome involved a sense of Alienation. As these ethnic minority students became more successful, they found themselves becoming alienated from their home communities and from themselves. "If I choose what I want to be, I cannot be what I was raised to be," was the way that Blake explained it. These students felt that they were being pushed by the school to expand and be open to change while, at the same time, they were being pulled by the people at home to return to old values. Ethnic minority women especially felt separated from the non-successful ethnic minority male.

The successful ethnic minority student often became alienated from family members, peers, community and self. Blake (1980) found that this type of Alienation leads to marginality. The marginal person is on the edge of two worlds but belongs to none. He is on the cutting edge. The student is moving away from the familiar to the unfamiliar. This becomes a strength and a basis for creativity. The transformation process becomes social with the impact of change and overcoming leading to constant marginality. Alienation means constantly being on the edge of discovery.

\section{Workshop Format}

When I returned to Duff's Business Institute where I was Academic Dean in 1980, I developed case studies based on three of our students who exhibited one or more academic syndromes. Then I developed a workshop to present to all of our Freshmen Seminar classes. The workshop consisted of the following:

1. An introduction to and discussion of the three academic syndromes.

2. Small group work with three case studies. Each group must come to consensus as they identify the syndromes in each case study, discuss their possible causes and recommend ways for a counselor to respond to the student in each case.

3. Class discussion of the findings of each group.

The case study format allowed students to discuss the syndromes without having to publicly admit to their own identification with them. 
The small groups were instructed to not only identify the syndromes and their causes within each case, but also recommend solutions for the problems of the student in the case. When the class then reconvened to discuss each groups responses, everyone in the class had a number of suggestions as to how to overcome their own feelings concerning Ultimate Doom, the Getting Over Pattern, and Alienation.

During the next five years, I presented this workshop every quarter to our beginning freshmen; a total of approximately 2,500 students. I had originally titled my presentation, "Academic Syndromes of Minority Students," but soon discovered that this was a mistake. After each workshop a number of students would remain behind to discuss how one of the syndromes was a perfect description of how they felt. Many of them were not ethnic minority students.

I can still remember a white (non-Hispanic) adult female student describing how her boyfriend beat her every night after classes and how he had finally resorted to locking her in the bathroom so that she couldn't come to school that morning. She had managed to climb out the bathroom window and get to class on time but wasn't sure how she was going to deal with him when she got home. Our class discussion of Alienation and the self esteem problem that an unemployed, uneducated male might have with seeing his significant other experiencing success in school, helped her plan a workable approach to her problem.

\section{Faculty Development}

In addition to working with freshmen, I modified the workshop for use in faculty development programs. I presented a revised version to the faculty at Duff's so that they would better understand what some of their students were experiencing and to help arm them with intervention strategies. This was also part of an overall school effort to improve student retention rates. The faculty version wasn't very different from the student workshop. During the introductory discussion, faculty were asked to contribute specific examples of students they believed were exhibiting symptoms of the three syndromes. When it came time for the small groups to work on the case studies, they were able to speak from personal experience. Rather than have 
them pretend to be school counselors, they were just asked to brainstorm what their responses as faculty should be for each case presented. The final large group discussion focused on specific suggestions for individual faculty dealing with students who exhibit symptoms of each syndrome.

The faculty confirmed for me what I had already discovered in the student workshops, that these academic syndromes applied to a large group of our students regardless of race, sex, age, or national origin. The faculty was also excited to have the opportunity to develop strategies to help students confront these problems in a proactive way rather than find many of these students dropping out of school for "personal problems."

Blake (1980) suggests three ways in which institutions can respond to these academic syndromes.

1. The academic program must respond to the developmental needs of students.

2. Faculty must nurture and recognize strengths in students that even the students may not be aware of.

3. Marginality must be seen as a basis for creativity. The cutting edge is the edge of discovery.

\section{Current Research}

During October and November 1994, I introduced these concepts to 114 students in five Success Skills classes (Freshmen Seminar) at Pittsburgh Technical Institute (PTI). I then surveyed each group to discover how many identified with each syndrome. The results were as follows:

114 total students were surveyed (15, or $13 \%$, were ethnic minority students).

$72(63 \%)$ identified with at least one syndrome.

16 (14\% of 114 and $22 \%$ of 72 ) identified with multiple syndromes.

12 identified with 2 syndromes.

4 identified with all 3 syndromes.

44 (39\%) identified with some form of Alienation.

$36(32 \%)$ said that they were into Getting Over. 
$12(8 \%)$ said that they had Ultimate Doom.

The five classes ranged from 21 to 26 students. The percent of students who identified with at least one syndrome by class was $76 \%$, $74 \%, 62 \%, 57 \%$ and $50 \%$. The mean was $63 \%$ of the students.

In January of 1995, I presented this workshop to another 51 freshmen (only 3 were ethnic minority students) with the following results:

$36(70 \%)$ identified with at least one syndrome.

8 (16\% of 51 and $22 \%$ of 36 ) identified with two syndromes.

$21(41 \%)$ identified with some form of Alienation.

12 (24\%) identified with Getting Over.

$11(22 \%)$ identified with Ultimate Doom.

The data show that students starting in the Winter term are more likely to have difficulties with Ultimate Doom than those who start in the Fall. While a higher percentage of students who start classes in the Fall are into Getting Over. One explanation for this could be that the Fall class consists mainly of students who have recently graduated from high school, while Winter starting classes often include students who have recently achieved their General Education Diploma or who have reluctantly decided to return to school.

During the Academic Syndromes' workshop for the faculty at PTI, I focused on the above statistics and delivered the following message:

These statistics show that these three major academic syndromes effect a majority of our new students and they effect some classes to a much greater extent than others. By identifying these syndromes early in the first quarter and helping students cope with their negative consequences, we should be able to reduce the number of students who withdraw from PTI or who fail unnecessarily.

We have now institutionalized a three-step process that includes follow through by faculty. Step one: present the Academic Syndromes workshop to all incoming freshmen. Step two: collect data from freshmen (self reported and anonymous) indicating which syndromes they identify in themselves. Step three: meet with each department's faculty to discuss the prevalence of the syndromes in their freshmen class that quarter and brainstorm specific supportive responses for the faculty to employ. 
This process has produced a student retention initiative by one department that is already showing signs of success. One Program Director compiled a list of problems that cause students to withdraw from school and then provided a list of possible solutions for each problem (school-based) for discussion with both faculty and students. After compiling fifty pages of solutions, she introduced a follow up discussion to the Academic Syndromes presentation in Freshman Seminar. The discussion covers many of the problems that cause students to drop out of school and empowers students with the solutions to those problems before they occur.

A number of faculty members have followed up on the student workshops by encouraging students to face their problems and deal with them. They tell students that rather than allow problems to grow to the point where they get too difficult and become potential reasons for leaving school, they need to be proactive in finding solutions. The faculty then steer individual students to the people who can help them with their problems.

\section{Discussion}

In 1984, Ellis provided the educational community with suggestions for developing a comprehensive plan for improving student retention. Included in his 30 suggestions were the following five:

- Identify potential dropouts.

- Make counseling available.

- Perform a climate check.

- Concentrate efforts on first-term students.

- Support warmth, friendliness and caring.

A first term workshop based on the three academic syndromes identified by Blake in the late '70's is an effective way to address some of the student retention issues in the '90's. Properly done, this workshop can help identify potential dropouts, provide counseling in a nonthreatening atmosphere, perform a climate check, focus on issues for first term students, and provide a caring atmosphere.

Once we realize that drop outs aren't the problem but dropping out is a solution that a student has implemented to solve a problem, 
then we can become part of the solution rather than part of the problem. If one of our jobs as educators is to help students learn to problem solve, why not begin the problem solving process with problems that effect many of our students. I am proposing that academic syndromes are a good place to start.

\section{References}

Blake, H. (1980, October). Beyond institutional development. Paper presented at the 9th Annual Professional and Organizational Development Conference, Berkeley, CA.

Ellis, D. (1984). Student retention strategies and teaching tech-niques: Excerpted from becoming a master student instructor's guide, (4th ed.). Rapid City, SD: College Survival Inc. 


\section{Appendix A}

\section{Academic Syndromes}

Case \#1 Jim Wilson attends PTI while also working full-time as a porter after school. He is a good student when he is in class and does well on exams. Recently, he has been missing classes and comes late when he does finally appear for class. When confronted with his behavior by his teachers, he offers a variety of excuses. A call to his parents reveals that he is the first in his family to continue schooling beyond high school and that none of his friends have gone on to school after graduating from high school.

Case \#2 Barbara works part-time as an administrative assistant while attending school. She arrives in class on time but never participates or completes homework assignments. She is attractive, charming, and makes an impressive appearance. When her teacher confronts her with her behavior, she states that she has no place to study because she lives at home with younger brothers and sisters who pester her all the time. She has no library in her area and no car available in the evening to travel across town to the library. Each day she speaks to her instructors about the problem and says that she will do better but the situation remains.

Case \#3 Alice is a 27-year old mother of three. Her husband is a high school drop out and construction worker. He is generally a kind man; however, since Alice began doing well at PTI, her husband has become cruel and hostile. He refuses to baby-sit while she studies, criticizes everything she does, and continually calls her "stupid." Recently he threatened to beat her for spending too much time with the books. The baby-sitter refuses to come to the house and as a result, Alice is frequently late for class or does not come at all. She is becoming frustrated and depressed and can't seem to concentrate on school. 


\section{Appendix B}

\section{Academic Syndromes}

Faculty Workshop

Directions

1. Choose a recorder for your group. This person will be responsible for recording the small group's reactions to the case problems and reporting the results to the large group at the end of this exercise.

2. Read each case and identify the syndrome or syndromes exhibited in the case. Identify the possible causes of the specific behaviors and suggest individual and institutional responses to each situation.

3. Discuss your thoughts concerning each case with your group. The recorder should note consensus and dissenting opinions concerning each case.

4. The recorder reports to the larger group identifying the group's consensus about the syndromes exhibited in each case, the possible causes of the specific behaviors, and suggested individual and institutional responses to each situation.

5. Individuals may bring up specific cases from their own classrooms for group discussion of possible responses. 